\title{
Diagnosis of lung cancer by fibreoptic bronchoscopy: problems in the histological classification of non-small cell carcinomas
}

\author{
MING T CHUANG, ALBERTO MARCHEVSKY, ALVIN S TEIRSTEIN, PAUL A \\ KIRSCHNER, JEROME KLEINERMAN
}

From the Mount Sinai Medical Center, New York, USA

ABSTRACT Specific cell typing in lung cancer has important implications for assessment of prognosis and the planning of treatment. Cell typing is, however, often difficult and the problem has been compounded by the universal use of the flexible fibreoptic bronchoscope, which yields specimens only $2 \mathrm{~mm}$ in diameter. We have reviewed the records of 107 patients who had a diagnosis of lung cancer established by fibreoptic bronchoscopy and who subsequently underwent staging biopsy or surgical resection. Examination of tissue obtained by surgical resection yielded a different cell type from that identified in specimens obtained at fibreoptic bronchoscopy in 11 of 32 patients with a bronchial biopsy specimen diagnostic of squamous cell, three of 44 patients with a diagnosis of adenocarcinoma, six of seven thought to have a poorly differentiated carcinoma, and 21 of 24 patients with a diagnosis of large cell carcinoma. In all, 41 of the 107 surgically removed specimens (38\%) differed in cell type from their corresponding bronchoscopic specimens. Accurate cell typing by specimens obtained at fibreoptic bronchoscopy may be extremely difficult. If clearcut morphological criteria cannot be satisfied, the diagnosis of "lung cancer, non-small cell type" should be made.

The histological classification of lung cancer is considered to be relevant to planning of treatment and to prognosis. Cell typing may be difficult, however, and the criteria are often non-uniform. The World Health Organisation has addressed the problem and has issued a revised schema for classification of pulmonary neoplasms by cell type.' Despite this interobserver and intraobserver discrepancies may occur because of the complex morphological characteristics of lung cancer.

The pathologist's difficulties have been compounded by the extensive use of fibreoptic bronchoscopy in the diagnosis of lung tumours. This procedure yields specimens about $2 \mathrm{~mm}$ in diameter, which frequently show tumour cells without any recognisable morphological pattern. Although the diagnosis of malignancy by fibreoptic bronchoscopic biopsy has proved to be extremely reliable, the

Address for reprint requests: Dr MT Chuang, Mount Sinai Medical

Accepted 18 October 1983 specific diagnosis of cell type often differs from the diagnosis made from specimens obtained after subsequent surgical extirpation. To assess the accuracy of the histological diagnosis of tumour cell type from biopsy specimens obtained by fibreoptic bronchoscopy we compared the diagnosis based on these specimens with that appearing in the pathologist's report based on the study of surgical specimens in 107 patients with lung cancer.

\section{Methods}

From January 1978 to June 1981107 patients who had a diagnosis of lung cancer made by fibreoptic bronchoscopy biopsy at the Mount Sinai Hospital, New York, underwent subsequent staging procedures such as mediastinoscopy, scalene lymph node biopsy, and/or surgical resection. The bronchoscopic biopsy was performed with $2 \mathrm{~mm}$ forceps by methods previously described. ${ }^{2}$ Biopsy specimens were taken under direct visualisation if an endobronchial mass was seen or by transbronchial lung biopsy under fluoroscopic guidance if no endobron- 
Table 1 Histological cell types in 107 patients diagnosed as having non-small cell carcinoma by flexible bronchoscopic biopsy and cell type of surgical specimens

\begin{tabular}{|c|c|c|c|c|c|c|}
\hline \multirow{2}{*}{$\begin{array}{l}\text { Flexible } \\
\text { bronchoscopy } \\
\text { diagnosis }\end{array}$} & \multirow[t]{2}{*}{ Total } & \multicolumn{5}{|c|}{ Surgical specimen diagnosis } \\
\hline & & $\begin{array}{l}\text { Squamous } \\
\text { cell } \\
\text { carcinoma }\end{array}$ & $\begin{array}{l}\text { Adeno- } \\
\text { carcinoma }\end{array}$ & $\begin{array}{l}\text { Large } \\
\text { cell } \\
\text { carcinoma }\end{array}$ & $\begin{array}{l}\text { Poorly } \\
\text { differentiated } \\
\text { carcinoma }\end{array}$ & Other \\
\hline $\begin{array}{l}\text { Squamous cell carcinoma } \\
\text { Adenocarcinoma } \\
\text { Large cell carcinoma } \\
\text { Poorly differentiated carcinoma }\end{array}$ & $\begin{array}{r}32 \\
44 \\
24 \\
7\end{array}$ & $\begin{array}{r}21 \\
1 \\
5\end{array}$ & $\begin{array}{r}3 \\
41 \\
14 \\
6\end{array}$ & $\begin{array}{l}4 \\
1 \\
3\end{array}$ & $\begin{array}{l}2 \\
1\end{array}$ & $\begin{array}{l}4^{*} \\
1 \dagger\end{array}$ \\
\hline
\end{tabular}

*One small cell carcinoma, three adenosquamous carcinomas.

$\dagger$ Mixed tumour.

chial lesion was visible. The tumours were classified by one of eight different qualified surgical pathologists according to the WHO classification of lung tumours. $^{3}$ The neoplasms were designated as squamous cell carcinomas in the presence of keratinisation or intracellular bridges or both. Adenocarcinomas showed glandular or papillary formation or had cells with intracellular mucicarmine or D-PAS positive material, or showed both features. Bronchoalveolar carcinomas were classified on the basis of their histological cell type and architectural pattern and were grouped with the adenocarcinomas. Tumours without any of the preceding morphological features were identified as either large cell carcinomas or poorly differentiated carcinomas. The original pathology reports were used in this study. All bronchoscopic diagnoses were lung cancers of one of the preceding cell types. No patient with an equivocal diagnosis of cancer was included in the study. Diagnoses made from fibreoptic bronchoscopic biopsy specimens were compared with those made from subsequent surgical specimens. Only non-small cell carcinomas were included in the analysis for this report.

\section{Results}

Forty one of the 107 patients $(38 \%)$ with broncho-

Table 2 Histological diagnosis from fibreoptic bronchoscopic (FOB) biopsy specimens and from surgical specimens in 107 patients with a bronchoscopic biopsy diagnosis of non-small cell carcinoma

\begin{tabular}{lll}
\hline FOB diagnosis & \multicolumn{2}{l}{$\begin{array}{l}\text { Diagnosis from surgical } \\
\text { specimen }\end{array}$} \\
\cline { 2 - 3 } & $\begin{array}{l}\text { Same as } \\
\text { FOB } \\
(\text { No) }\end{array}$ & $\begin{array}{l}\text { Different from } \\
\text { FOB } \\
(\text { No }(\%))\end{array}$ \\
\hline & 3 & $21(87 \cdot 5)$ \\
Large cell carcinoma & 1 & $6(85 \cdot 7)$ \\
Poorly differentiated carcinoma & 21 & $11(34 \cdot 4)$ \\
Squamous cell carcinoma & 41 & $3(6 \cdot 8)$ \\
Adenocarcinoma & 66 & $41(38 \cdot 0)$ \\
Total & & \\
\hline
\end{tabular}

scopically proved lung cancer had histological cell types in the subsequent surgical specimens that differed from those in the original biopsy reports (table 1). Eleven of 32 patients with specimens classified as squamous cell carcinoma on bronchoscopic biopsy had a different histological cell type of carcinoma on examination of the surgically obtained specimen (four large cell and three adenosquamous carcinoma, three adenocarcinoma, and one small cell carcinoma). Three of 44 patients with diagnosis of adenocarcinoma by bronchoscopic biopsy had different diagnoses of cell type after examination of the surgical specimens (one squamous cell, one large cell, and one benign mixed tumour). Large cell carcinoma was identified by bronchoscopic biopsy in 24 patients, but this classification was supported by surgical specimens in only three patients. Of the remaining 21 patients with a bronchoscopic diagnosis of large cell carcinoma, 14 were later found to have adenocarcinoma, five squamous cell carcinoma, and two poorly differentiated carcinoma at surgery. Six of seven patients whose specimens were reported as poorly differentiated carcinoma on bronchoscopic biopsy subsequently were diagnosed as having adenocarcinoma.

A diagnosis of poorly differentiated or large cell cancer made from the biopsy specimen was associated with a later different diagnosis in the surgical specimens in more than $85 \%$ of cases (table 2 ). In 29 instances both specimens were read by the same

Table 3 Diagnosis of cell type based on fibreoptic bronchoscopic biopsy specimens and on surgical specimens when the same and different pathologists studied the two specimens

\begin{tabular}{llcl}
\hline Pathologists & $\begin{array}{l}\text { No of } \\
\text { patients } \\
\text { studied }\end{array}$ & $\begin{array}{l}\text { No (\%) of cases } \\
\text { with different } \\
\text { diagnoses }\end{array}$ \\
\hline $\begin{array}{l}\text { Same } \\
\text { Different } \\
\text { Total }\end{array}$ & $\begin{array}{l}\text { for the two } \\
\text { specimens }\end{array}$ & $\begin{aligned} 78 \\
107\end{aligned}$ & $\begin{array}{l}10(34 \cdot 5)^{*} \\
41(39 \cdot 7)^{*}\end{array}$ \\
\hline
\end{tabular}

${ }^{*} \chi^{2}$ test shows no significant difference. 
pathologist, while in 78 different pathologists read the two specimens. The frequency of different diagnoses by cell type was similar in these two groups $(34.5 \%$ and $39.7 \%)$. The difference was not significant (table 3 ).

\section{Discussion}

Differences between pathologists in the histological diagnosis of lung cancer are not unexpected. In a study of 50 surgically resected specimens Feinstein reported considerable variability in the histopathological diagnosis of cancer cell type among five experienced pathologists. ${ }^{4}$ These experts disagreed in $2-5 \%$ of well differentiated squamous cell carcinomas and adenocarcinomas, in $25-35 \%$ of undifferentiated or small cell carcinomas, and in $40-42 \%$ of poorly differentiated squamous cell carcinomas or adenocarcinomas. There was also appreciably different diagnostic interpretation when the same pathologist was asked to review the same slides at a later date. These discrepancies were attributed to the presence of multiple cell types within the same tumour and to the subjective interpretation of morphological features such as the presence of intracellular bridges, keratinisation, and intracytoplasmic mucin formation. The pathologist's task becomes much more difficult when he attempts to make a specific diagnosis of tumour cell type by using study of $2 \mathrm{~mm}$ biopsy samples obtained by fibreoptic bronchoscopy. This is especially true in the diagnosis of poorly differentiated carcinoma and large cell carcinoma (table 2). This variability of diagnosis of cancer cell type when fibreoptic bronchoscopic specimens are compared with subsequent surgical specimens is probably due in part to lack of sufficient material to identify the specific morphological features necessary for the classification of a pulmonary neoplasm, and in part to observer variation as reported by Feinstein and associates. ${ }^{4}$ We compared the original biopsy reports and subsequent reports based on surgical specimens and did not review the earlier slides. Our results therefore reflect the unaltered daily practice of pathologists concerned with routine care of patients in a medical centre. Table 3 shows that the frequency of discrepancies was similar in the two groups, suggesting that interobserver variability was not contributing to the problem in our series.

Specific cell typing of lung cancer is clinically important. It is currently believed that squamous cell carcinoma carries a better prognosis for survival than does adenocarcinoma of the lung. ${ }^{5}$ It has been suggested that surgical intervention is contraindicated in patients with adenocarcinoma who have mediastinal lymph node metastases, while some authorities urge resection under similar circumstances when the histological diagnosis is squamous cell carcinoma. ${ }^{67}$ Clee et $a^{8}$ have emphasised the importance of accurate cell typing in evaluating the results of chemotherapy in lung cancer. They underline the need for a precise histological diagnosis for development of effective chemotherapeutic protocols. So far the best results of chemotherapy in lung cancer have been obtained in the treatment of small cell carcinoma. ${ }^{9}$ Unfortunately, the results of chemotherapy for non-small cell lung cancer of all cell types are usually poor. While an occasional patient shows a favourable response, most obtain no benefit or only brief, transient regression of their tumour. Currently the diagnosis of a non-small cell carcinoma has limited clinical significance. On the other hand, the differentiation of small cell from non-small cell carcinomas appears to be of major clinical importance. It is generally agreed that the patients with small cell carcinomas should be spared surgery and that they may expect to obtain worthwhile benefit from chemotherapy, ${ }^{910}$ while every effort should be made to resect non-small cell carcinomas when metastases are absent or limited to local mediastinal lymph nodes. ${ }^{67}$ We suggest therefore that, for clinical purposes, the pathologist should identify the specific cell type of a lung cancer after analysis of small samples only when unequivocal morphological criteria are met. In instances where the tumour is poorly differentiated or where clearcut histological criteria are not met, it should be classified as "carcinoma, non-small cell type."

\section{References}

' World Health Organisation. The World Health Organisation histological typing of lung tumours. 2nd ed. Am J Clin Pathol 1982;77:123-36.

${ }^{2}$ Teirstein AS, Chuang M, Miller A. Application of the flexible bronchoscope. Mt Sinai $J$ Med NY 1975;42:81-94.

${ }^{3}$ Kreyberg L, Liebow AA, Uehlinger EA. Histological typing of lung tumours. Geneva: World Health Organisation, 1967. (International Histological Classification of Tumours, No 1.)

${ }^{4}$ Feinstein AR, Gelfman NA, Yesner R, Auerbach O, Hackel DB, Pratt, PC. Observer variability in the histopathologic diagnosis of lung cancer. Am Rev Respir Dis 1970;101:671-84.

${ }^{5}$ Mountain CF. The relationship of prognosis to morphology and the anatomic extent of disease. In: Israel L, Chahinian P, eds. Lung cancer: natural history, prognosis and therapy. New York: Academic Press, 1976:107-40.

${ }^{-}$Rubinstein I, Baum GL, Kalter Y, Pauzner Y, Lieberman Y, Bubis JJ. The influence of cell type and lymph node metastases on survival of patients with carcinoma of the lung undergoing thoractomy. Am Rev Respir Dis 1979;119:253-62.

${ }^{7}$ Pearson FG, Nelems JM, Henderson RD, Delarue NC. 
The role of mediastinoscopy in the selection of treatment for bronchial carcinoma with involvement of superior mediastinal lymph nodes. $J$ Thorac Cardiovasc Surg 1972;64:382-90.

${ }^{8}$ Clee MD, Duguid HLD, Sinclair DJM. Accuracy of morphological diagnosis of lung cancer in a depart- ment of respiratory medicine. $J$ Clin Pathol 1982;35:414-9.

${ }^{9}$ Greco FA, Oldham RK. Current concepts in cancer: small-cell lung cancer. $N$ Engl J Med 1979;301:355-8.

${ }^{10}$ Weiss RB. Small-cell carcinoma of the lung: therapeutic management. Ann Intern Med 1978;88:522-31.

\section{Book notices}

Diagnostic Tumour Bibliographies I-Tumours of the Trachea, Bronchus, Lung and Pleura. WF Whimster. (Pp. 167; £20.) Pitman Books. 1983.

A book of 167 pages of tumour bibliography covering tumours of the trachea, bronchus, lung and pleura sounds a fairly dry tome. This volume covers a total of 70 tumour or tumour like conditions which have been reported as having occurred in the lung. For each there is a brief introduction with key references, and the author's brief and pithy comments are valuable and interesting. There follows a list of references in which best accounts are identified and single one line comments indicate the importance of individual references. The number of references included has been finely judged, the references being selected and adequate, but not so many as to be off putting. Despite its severe presentation this is a fascinating book. Even those interested in the field are likely to find many unfamiliar references among the better known ones. The brief comments are just sufficient to whet the appetite and send the reader back to the library. This is an essential reference book for anyone interested in diagnosis or management of tumours of the lung, pathologist or clinician. The price is high, but the book is well worth it.-D L

Physiology of the Lung. TPK Lim. (Pp 185; \$16.75spiral, paper binding.) Charles C Thomas. 1983.

The basis of this book is a straightfoward account of conventional pulmonary physiology. The author has compressed a remarkable amount of physiological information into a small space and still left room for interesting examples and asides. In addition to sections dealing with standard pulmonary physiology there are chapters on hypoxia, altitude and diving, and respiratory treatment. A final chapter contains short case histories with pulmonary func- tion tests-each followed by multiple choice questions. The reader who is already familiar with the subject matter will find that the book reads easily, but the condensed presentation will probably make it difficult for the novice to assimilate the more complex passages. Teachers and students of pulmonary physiology should be aware of the book as a perfectly adequate basic text on the subject, but most students will probably opt for one of several other works offering a more selective and more explanatory approach.-RALB

Methods for Cohort Studies of Chronic Airflow Limitation. $\mathrm{C}$ du V Florey and SR Leeder. (Pp 134; Sw fr 19.) Copenhagen: World Health Organisation (European Series No 12). 1982.

This booklet provides an introduction to investigators setting up studies of chronic respiratory disease, covering approaches to sample size, questionnaires, lung function tests, data preparation, statistical analysis, and record keeping. A major and useful part of the booklet reproduces in full the various questionnaires used by the Medical Research Council in Britain, the ATS-DLD version used in North America, and others developed by WHO and the EEC for use with children. The advice is simply written and model calculations are given to illustrate some of the techniques and problems. Less guidance is provided on the critical question of how to handle the data gathered, except to state that analytical methods for repeated measures for cohort data are "perhaps less advanced than those for cross-sectional data." Such topics as expected rates of change in lung function, the role of $\mathrm{FEV}_{1}$ level in annual decline in $\mathrm{FEV}_{1}$, and the use of bronchodilators are not addressed, so that the intending investigator would be well : advised to complement this somewhat theoretical check list of initial study design by reading a description of a completed practical example such as the monograph The Natural History of Chronic Bronchitis and Emphysema by Fletcher and colleagues. 